\title{
Genetic analyses of Bantam and selected low-weight White Plymouth Rock chickens and their crosses. II. Onset of sexual maturity and egg production
}

\author{
EA Dunnington *, PB Siegel \\ Virginia Polytechnic Institute and State University \\ Poultry Science Department, Blacksburg, VA 24061-0332, USA
}

(Received 30 April 1990; accepted 18 January 1991)

\begin{abstract}
Summary - Two generations of crosses between a population of White Plymouth Rock Bantams and a line of White Plymouth Rocks selected for low body weight for 31 generations were produced. Characteristically, the Bantams had produced a high proportion of normal eggs, but hen-day normal egg production in this population was low. The hens selected for low body weight also produced a high proportion of normal eggs, but age at sexual maturity had been greatly delayed as a correlated response to selection. In the 16 populations involving parental lines and crosses ( $\mathrm{F}_{1}, \mathrm{~F}_{2}$ and backcrosses), age at onset of sexual maturity and egg production traits were measured. Comparisons of these populations suggested that age at sexual maturity was influenced by sex linkage, by one or more genes with major effects and by other genes with lesser effects. When compared to performance of the parental populations, some measures of reproductive fitness were improved by crossing (age at first semen production, age at first egg, hen-day normal egg production). Other traits were not changed by crossing (percent normal eggs, duration of fertility).
\end{abstract}

selection / Bantam / chickens / sexual maturity / egg production

Résumé - Analyses génétiques de deux lignées de poules Plymouth Rock Blanche, l'une Bantam et l'autre sélectionnée pour un faible poids, et de leurs croisements. II. Apparition de la maturité sexuelle et ponte. Deux générations de croisement ont été produites à partir d'une population de poules Plymouth Rock Blanche Bantam et d'une lignée de Plymouth Rock Blanche sélectionnée pour un faible poids corporel pendant 31 générations. D'une manière caractéristique, les Bantam produisaient une proportion élevée d'œufs normaux, mais la production journalière d'œufs normaux dans cette population était faible. Les poules sélectionnées pour un faible poids corporel produisaient aussi une proportion élevée d'œufs normaux, mais l'âge à la maturité sexuelle était fortement augmenté, en réponse indirecte à la sélection. Dans les 16 populations impliquant les lignées parentales et les croisements $\left(F_{1}, F_{2}\right.$ et croisements en retour), l'âge à la maturité sexuelle et les caractères de ponte étaient mesurés. Les comparaisons entre ces populations suggèrent que l'âge à la maturité sexuelle est influencé par des gènes liés au sexe, par un ou

* Correspondence and reprints 
plusieurs gènes à effet majeur et par d'autres gènes à effets moins importants. Relativement aux populations parentales, certaines mesures de l'aptitude reproductive étaient améliorées par le croisement (âge à la première production de semence, âge au premier auf, production journalière d'aufs normaux). Les autres caractères n'étaient pas modifiés par le croisement (pourcentage d'oeufs normaux, durée de la période fertile).

sélection / Bantam / poule / maturité sexuelle / ponte

\section{INTRODUCTION}

Artificial selection for traits of economic importance in domestic animal species often results in reduced reproductive fitness. This effect is particularly common when growth rate and growth patterns are altered (Siegel and Dunnington, 1985). A finite and often limited pool of resources available to an individual at any given time must be allocated to all needs, including growth, maintenance, deposition of fat and protein, resistance to infectious agents, and reproduction (Dunnington, 1990). Intense selection for one or a few of these factors may leave the individual without sufficient resources for the others (Lerner, 1954; Dunnington, 1990).

Long-term selection for lower body weight in White Plymouth Rock chickens has been accompanied by many correlated responses, including reduced appetite and impaired reproductive capabilities (Dunnington et al, 1984; Dunnington and Siegel, 1985). Lack of appetite in such a line developed in our laboratory has become so pronounced that mortality from starvation occurs during the first week. Many of the pullets that survive are anorexic - that is, they eat enough food on an ad libitum basis to survive, but not enough to attain sexual maturity. When forcefed, these pullets commence egg production in a short time (Zelenka et al, 1988). The pullets that do mature, either by force-feeding or with ad libitum feeding, generally produce a high proportion of normal eggs. Several studies have detailed differences in pullets that do and do not mature at particular ages and/or particular body sizes in this population (Zelenka et al, 1986a, b, 1987).

The long-term selection experiment in which these chickens were developed has reached a limit for low 8-wk body weight (Dunnington et al, 1987). When the population mean for body weight of pullets at $8 \mathrm{wk}$ of age (age at selection) reaches $\approx 170 \mathrm{~g}$, many of the smallest individuals never become sexually mature, effectively arresting selection for lower body weight in the next generation (Siegel and Dunnington, 1987). When selection is relaxed (because the smallest individuals do not reproduce), the problem of anorexia is alleviated in the next generation. This selection limit has been approached 3 times in the last 6 generations, but has not been broken. In an attempt to study this situation further, White Plymouth Rock Bantams were obtained to cross with chickens from this low-weight selected line. Characteristically, the Bantams matured at rather young ages and produced a high proportion of normal eggs, but hen-day normal egg production was low. Generally, heterosis for age at sexual maturity is found (Komiyama et al, 1984). Therefore, offspring produced by crossing low-weight and Bantam lines should retain their small size but might improve in reproductive capabilities.

The influence of a major gene on age at sexual maturity in pullets was reported more than half a century ago (Hays, 1924; Warren, 1928, 1934). More recent work has generally treated this trait as quantitative - influenced by a number of genes, 
each with small effects. The experiment reported here allows testing of the major gene theory for age at sexual maturity in chickens.

The objective of this study was to evaluate genetic aspects of age at sexual maturity and egg production traits in parental, $F_{1}, F_{2}$ and backcross populations produced from matings involving White Plymouth Rock Bantam and White Plymouth Rock low-weight selected chickens. The influence of a major gene and of sex-linkage on age at sexual maturity of these populations was examined.

\section{MATERIALS AND METHODS}

White Plymouth Rock Bantams (supplied by CJ Wabeck, University of Maryland) and a line of White Plymouth Rocks that had been selected for 31 generations for low 8-wk body weight (Dunnington and Siegel, 1985) were crossed. The 4 resulting populations: $\mathrm{BB}, \mathrm{BL}, \mathrm{LB}$ and $\mathrm{LL}$ (first letter designates sire line and second letter dam line) were hatched on September 15, 1988. These chicks were wingbanded, vaccinated for Marek's disease and raised on litter in floor pens with ad libitum feed and water. At $18 \mathrm{wk}$ of age, 20 randomly chosen males per population were moved into individual cages in an environmentally controlled room with continuous light to provide semen for production of the next generation. Random samples of 50 pullets per population were housed in the same facility. For pullets, age and body weight at sexual maturity (production of first egg), weight of first egg and egg production were recorded. Egg production data were used to calculate percent normal eggs [\% $\mathrm{NE}=($ Number of normal eggs / total eggs produced $) \cdot 100]$ and hen-day normal egg production [\% HDNEP $=$ (Number of normal eggs $/$ Number of days each hen was in production) - 100].

Parental, and all possible $F_{1}, F_{2}$ and backcross chicks were produced from the 4 populations. Details of the mating scheme have been presented (Dunnington and Siegel, 1991). Designations for the 16 populations in this generations are 4 letters, the first 2 indicating the sire's line and the second 2 the dam's line. Semen from 20 males per population was pooled to inseminate the appropriate females. Seventyfive -80 females per population were used to produce eggs.

For the offspring produced (hatched 2 May, 1989) by crossing of BB, BL, LB and LL chickens, randomly chosen samples of 15 males per line were placed in cages and checked weekly from 6 wk of age for semen production. Age at production of first semen was recorded as the age of sexual maturity for each male.

Randomly chosen samples of 20 females per line were housed in individual cages at 18 wk of age. Age and body weight at production of first egg were recorded, as well as weights of the first and the 10th normal eggs laid. Age at first egg was considered age at sexual maturity. Egg production of each pullet was recorded for 60 consecutive $d$ after onset of sexual maturity. Egg production data were used to calculate \% NE and \% HDNEP. Pullets that reached $265 \mathrm{~d}$ of age without maturing sexually were dropped from the study. At 185 and again at $188 \mathrm{~d}$ of age, 10 females per line were artificially inseminated with pooled semen from at least 10 males of an unrelated White Leghorn line. Duration of fertility was then assessed by breaking open every egg on the day it was laid and classifying it as fertile or infertile by macroscopic inspection (Kosin, 1945). When a pullet laid 2 consecutive 
infertile eggs, she was assumed to be infertile and the day of her last fertile egg was recorded to designate duration of fertility.

Analysis of variance and Duncan's multiple range tests were conducted to ascertain differences between lines in generation 1 (4 populations), and the same populations were analyzed in generation 2 to compare results for 2 generations. In generation 2, progeny from the 16 mating combinations were compared by analyses of variance and contrasts were conducted to ascertain differences due to the following effects: parental, reciprocal, heterosis and recombination. The specific contrasts are defined in the footnote of table II. Weiglts were transformed to common logarithms and percentages to arc sine square roots prior to analyses.

Analysis of the populations in this study allowed examination of the influence of a major gene on age at sexual maturity. Comparisons of combined frequency distributions of the backcrosses to one parental line with combined frequency distributions of the parental and $F_{1}$ crosses indicate whether one locus or more is involved (Stewart, 1969). If there is no difference between these 2 sets of means, one locus is sufficient to explain the situation.

\section{RESULTS}

\section{Comparisons of parental and reciprocal $F_{1}$ populations}

Results from the 4 populations in generation 1 (BB, BL, LB, and LL) and the same populations in generation 2 (BBBB, BBLL, LLBB, and LLLL) for age at sexual maturity in females were quite similar (table I). Age at first egg was earliest in cross $\mathrm{BL}$, latest in parental line $\mathrm{LL}$ and intermediate for populations $\mathrm{BB}$ and $\mathrm{LB}$. This difference in the reciprocal $F_{1}$ populations suggested a sire-line effect for the trait. Both body weight at first egg and weight of the first egg were lowest in the pure Bantams, and progressively higher for lines BL, LB and LL, respectively. Hens of the 4 populations produced essentially all normal eggs, but there were differences in $\%$ HDNEP. This trait was lowest in BB, higher in LL and highest in the reciprocal $\mathrm{F}_{1}$ crosses (table I). In addition to the similarity of mean age at onset of egg production in the 2 generations of this study, frequency distributions of age at first egg were also similar (fig 1).

\section{Comparisons of 16 populations}

By $265 \mathrm{~d}$ of age all pullets in most lines had reached sexual maturity. Numbers of pullets that did not begin to produce eggs by this age were: 1 (BLLL), 2 (LBLL), 1 (LLBB), 2 (LLBL) and 3 (LLLL). These few immature pullets were omitted from the analysis. There were significant differences between parental populations for all traits (table II) except \% NE and duration of fertility (data not shown). In each case, means were higher for line L than line B. Reciprocal effects were significant for maturity of males, age and body weight at first egg of females and weights of lst and 10th eggs. Influence of heterosis was evident for age at sexual maturity in both sexes (males, $-11 \%$, females, $-16 \%$ ), body weight at first egg $(6 \%)$ and $\%$ HDNEP (45\%). Effects of recombination were significant only for age at first egg $(9 \%)$ and $\%$ HDNEP $(-15 \%)$. 


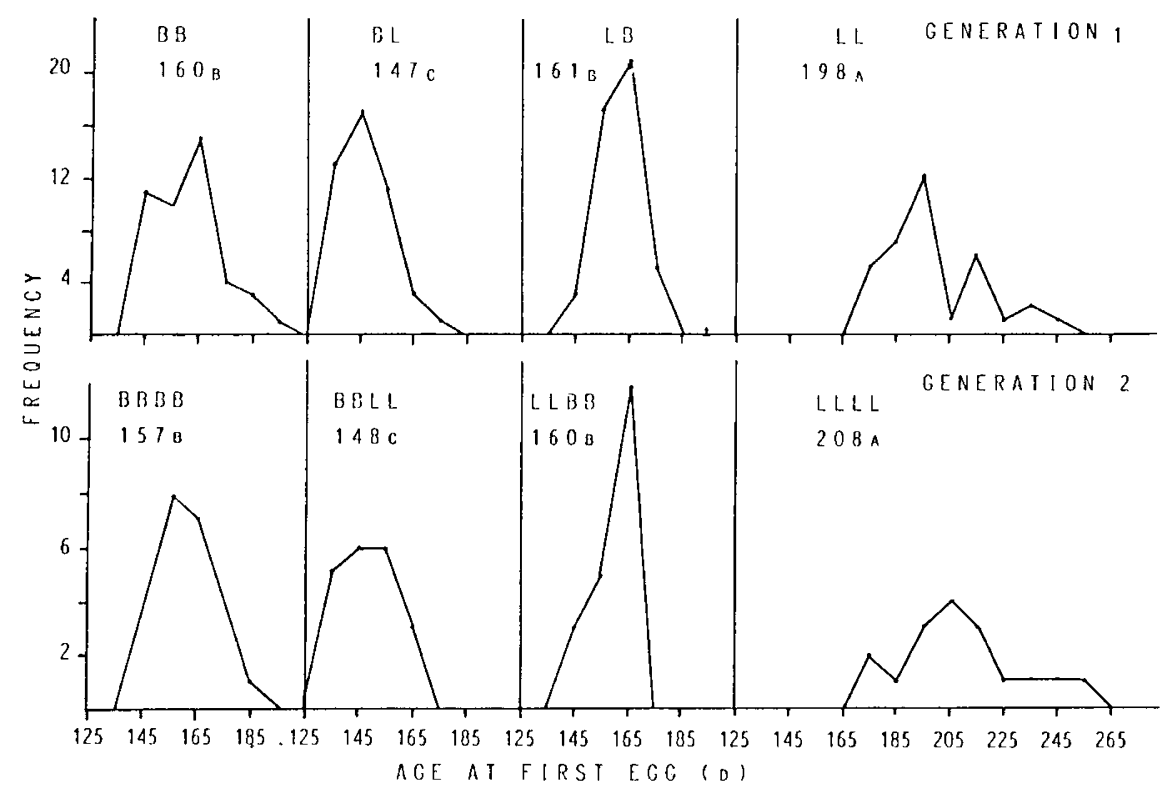

Fig 1. Frequency distributions for age at first egg in chickens from Bantam (B) and low-weight $(\mathrm{L})$ parental lines and their $F_{1}$ reciprocal crosses in generation $1(\mathrm{BB}, \mathrm{BL}$, LB, LL) and 2 (BBBB, BBLL, LLBB, LLLL). Means within a generation with different superscripts were significantly different $(P<0.05)$.

Table I. Means ${ }^{1} \pm \mathrm{SEM}$ of egg production traits for Bantam $(B B)$ and low-weight $(L L)$ parental populations and reciprocal $\mathrm{F}_{1}$ crosses $(B L, L B)$ for generations 1 and 2 .

\begin{tabular}{lrrrrr}
\hline & Generation & $B B$ & $B L$ & \multicolumn{1}{c}{$L B$} & \multicolumn{1}{c}{$L L$} \\
\hline Age at lst egg (d) & 1 & $160 \pm 2 \mathrm{~b}$ & $147 \pm 1 \mathrm{c}$ & $161 \pm 1 \mathrm{~b}$ & $198 \pm 3 \mathrm{a}$ \\
& 2 & $157 \pm 2 \mathrm{~b}$ & $148 \pm 2 \mathrm{c}$ & $160 \pm 1 \mathrm{~b}$ & $208 \pm 6 \mathrm{a}$ \\
BW at lst egg (g) & 1 & $757 \pm 16 \mathrm{~d}$ & $959 \pm 12 \mathrm{c}$ & $1136 \pm 16 \mathrm{~b}$ & $1234 \pm 15 \mathrm{a}$ \\
& 2 & $779 \pm 28 \mathrm{~d}$ & $998 \pm 22 \mathrm{c}$ & $1146 \pm 24 \mathrm{~b}$ & $1239 \pm 27 \mathrm{a}$ \\
Weight of lst egg (g) & 1 & $26 \pm 0.3 \mathrm{~d}$ & $27 \pm 0.3 \mathrm{c}$ & $30 \pm 0.4 \mathrm{~b}$ & $32 \pm 0.4 \mathrm{a}$ \\
& 2 & $26 \pm 0.5 \mathrm{~d}$ & $28 \pm 0.7 \mathrm{c}$ & $30 \pm 0.7 \mathrm{~b}$ & $33 \pm 0.9 \mathrm{a}$ \\
\% NE $^{2}$ & 1 & $99.8 \pm 0.1 \mathrm{a}$ & $99.9 \pm 0.1 \mathrm{a}$ & $99.7 \pm 0.1 \mathrm{a}$ & $99.9 \pm 0.1 \mathrm{a}$ \\
& 2 & $98.8 \pm 0.8 \mathrm{a}$ & $99.9 \pm 0.1 \mathrm{a}$ & $99.1 \pm 0.3 \mathrm{a}$ & $99.6 \pm 0.6 \mathrm{a}$ \\
\% HDNEP $^{3}$ & 1 & $37 \pm 2 \mathrm{c}$ & $74 \pm 1 \mathrm{a}$ & $76 \pm 2 \mathrm{a}$ & $63 \pm 3 \mathrm{~b}$ \\
& 2 & $47 \pm 4 \mathrm{c}$ & $82 \pm 2 \mathrm{a}$ & $78 \pm 2 \mathrm{a}$ & $63 \pm 4 \mathrm{~b}$ \\
\hline
\end{tabular}

a, b... Means within a row with different letters are significantly different $(P<0.05)$. ${ }_{1}^{1}$ Number of observations per mean ranged from $43-50.2 \% \mathrm{NE}=$ (Number of normal eggs/total Number of eggs $100{ }^{3} \%$ HDNEP $=$ (Number of normal eggs/Number of days in production) $\cdot 100$. 
Table II. Means ${ }^{1} \pm$ SEM for sexual maturity (males and females), body weight at lst egg $(B W 1 E G G)$, and \% hen-d normal egg production (HDNEP) from all mating combinations of Bantam and low-weight populations.

\begin{tabular}{|c|c|c|c|c|}
\hline Population & $\begin{array}{l}\text { Age at } \\
\text { lst semen } \\
\text { production (d) }\end{array}$ & $\begin{array}{l}\text { Age at } \\
\text { lst } \\
\text { egg (d) }\end{array}$ & $B W 1 E G G(g)$ & HDNEP (\%) \\
\hline \multicolumn{5}{|l|}{ Parental } \\
\hline BBBB & $85 \pm 2 \mathrm{~cd}$ & $157 \pm 2 \mathrm{f}-\mathrm{h}$ & $779 \pm 28 \mathrm{~h}$ & $47 \pm 4 \mathrm{e}$ \\
\hline LLLL & $106 \pm 4 \mathrm{a}$ & $208 \pm 6 \mathrm{a}$ & $1239 \pm 27 \mathrm{ab}$ & $63 \pm 4 \mathrm{~cd}$ \\
\hline \multicolumn{5}{|l|}{$\mathrm{F}_{1}$} \\
\hline BBLL & $88 \pm 2 \mathrm{~cd}$ & $148 \pm 2 \mathrm{i}$ & $999 \pm 22$ ef & $82 \pm 2 \mathrm{a}$ \\
\hline LLBB & $82 \pm 1 \mathrm{~d}$ & $160 \pm 1 \mathrm{e}-\mathrm{g}$ & $1146 \pm 24 \mathrm{~b}-\mathrm{d}$ & $78 \pm 2 a b$ \\
\hline \multicolumn{5}{|l|}{$\mathrm{F}_{2}$} \\
\hline BLBL & $84 \pm 2 \mathrm{~cd}$ & $173 \pm 4 \mathrm{~b}-\mathrm{d}$ & $1056 \pm 32 \mathrm{de}$ & $63 \pm 4 \mathrm{~cd}$ \\
\hline BLLB & $90 \pm 2 b c$ & $168 \pm 4 \mathrm{~b}-\mathrm{e}$ & $1129 \pm 39 \mathrm{~cd}$ & $63 \pm 5 \mathrm{~cd}$ \\
\hline LBBL & $88 \pm 2 \mathrm{~cd}$ & $164 \pm 3 \mathrm{c}-\mathrm{g}$ & $1116 \pm 36 \mathrm{~cd}$ & $77 \pm 2 a b$ \\
\hline LBLB & $88 \pm 3 \mathrm{~cd}$ & $166 \pm 3 \mathrm{c}-\mathrm{f}$ & $1049 \pm 21 \mathrm{de}$ & $70 \pm 3 \mathrm{~b}-\mathrm{d}$ \\
\hline \multicolumn{5}{|l|}{ Backcross to $\mathrm{B}$} \\
\hline BBBL & $84 \pm 1 d$ & $150 \pm 2 \mathrm{hi}$ & $891 \pm 24 \mathrm{~g}$ & $69 \pm 2 b-d$ \\
\hline BBLB & $86 \pm 2 \mathrm{~cd}$ & $147 \pm 1 \mathrm{i}$ & $927 \pm 24 \mathrm{fg}$ & $71 \pm 2 \mathrm{~b}-\mathrm{d}$ \\
\hline BLBB & $84 \pm 1 d$ & $156 \pm 3 \mathrm{~g}-\mathrm{i}$ & $901 \pm 35 \mathrm{~g}$ & $64 \pm 3 \mathrm{~cd}$ \\
\hline LBBB & $84 \pm 1 d$ & $161 \pm 2 \mathrm{e}-\mathrm{g}$ & $939 \pm 26 \mathrm{fg}$ & $61 \pm 4 \mathrm{~d}$ \\
\hline \multicolumn{5}{|l|}{ Backcross to $\mathrm{L}$} \\
\hline BLLL & $88 \pm 1 \mathrm{~cd}$ & $167 \pm 4 \mathrm{~b}-\mathrm{e}$ & $1178 \pm 34 \mathrm{bc}$ & $74 \pm 3 \mathrm{a}-\mathrm{c}$ \\
\hline LBLL & $91 \pm 3 b c$ & $172 \pm 4 \mathrm{~b}-\mathrm{d}$ & $1150 \pm 39 \mathrm{~b}-\mathrm{d}$ & $65 \pm 5 \mathrm{~cd}$ \\
\hline LLBL & $85 \pm 2 \mathrm{~cd}$ & $174 \pm 3 \mathrm{bc}$ & $1246 \pm 24 \mathrm{ab}$ & $70 \pm 3 \mathrm{~b}-\mathrm{d}$ \\
\hline LLLB & $98 \pm 4 \mathrm{~b}$ & $176 \pm 4 \mathrm{~b}$ & $1283 \pm 26 \mathrm{a}$ & $70 \pm 5 \mathrm{~b}-\mathrm{d}$ \\
\hline \multicolumn{5}{|l|}{ Contrasts $^{2}$} \\
\hline Parental & $* *$ & $* *$ & $* *$ & $* *$ \\
\hline Reciprocal & $*$ & $* *$ & $* *$ & - \\
\hline Heterosis & $* *$ & $* *$ & $* *$ & $* *$ \\
\hline Recombination & - & $* *$ & - & $* *$ \\
\hline
\end{tabular}

a, b,.. Means, within a column with the same letter are not significantly different $(P>0.05)$. 1 Number of observations per mean ranged from 17-20. 2 Contrasts : Parental = BBBB-LLLL. Reciprocal = BBLL-LLBB. Heterosis = $(B B L L+L L B B)-$ $(\mathrm{BBBB}+\mathrm{LLLL})$. Recombination = $(\mathrm{BLBL}+\mathrm{BLLB}+\mathrm{LBBL}+\mathrm{LBLB})-2 \cdot(\mathrm{BBLL}+\mathrm{LLBB})$. $* *(P<0.01), * *(P<0.05),-(P>0.05)$.

For age at first egg, lack of significant differences when comparing combined frequency distribution of the parental $B B B B$ and reciprocal $F_{1}$ crosses to the combined frequency distribution of the backcrosses to $\mathrm{B}$ (calculated $\chi^{2}=3.25$, $\mathrm{dF}=3$, theoretical $\chi^{2}=7.81$ ) indicated that 1 locus is sufficient to explain this situation. That is, there appears to be a major gene influencing age at sexual maturity in these Bantam pullets. Conversely, the significant difference between combined frequency distribution of the backcrosses to the LL with the combined 
frequency distribution of the parental LLLL and $F_{1}$ crosses (calculated $\chi^{2}=42.34$, $\mathrm{dF}=7$, theoretical $\chi^{2}=14.1$ ) indicates the absence of such a major gene in LLLL pullets. Because there was a difference between the reciprocal $F_{1}$ crosses in age at first egg, with each $F_{1}$ cross of pullets resembling more closely its sire line, this gene appears to be sex-linked. Contrasts within each set of 4 backcross populations to evaluate contribution of sire line provided additional support that pullets have inherited the gene for early sexual maturity from their sires (see means, table II). The situation for sexual maturity for males is less clear because each male receives half of the genetic influence for the trait from each parent. Contrasts between the backcrosses to $\mathrm{B}$ and the backcrosses to $\mathrm{L}$ in age at first production of semen, however, were significant (see means, table II), suggesting a dosage effect in which individuals which were $75 \% \mathrm{~B}$ matured at younger ages than those which were $75 \% \mathrm{~L}$.

\section{DISCUSSION}

\section{Genetic control of age at sexual maturity}

Shapes of the frequency distributions of age at first egg in generation 1 prompted us to produce generation 2 for further study. The overdominance of $F_{1}$ cross BL suggested that an effect of sire line for sexual maturity in females (ie, sex-linkage) was present. Also, the bimodal shape of the distribution for LL females implied that a major gene may be influencing the trait. The ideas that onset of egg production is sex-linked and may be influenced by one or a few genes with major effects were reported in the literature early in this century (eg, Hays, 1924; Warren, 1928, 1934), but later research has treated the trait as a quantitative one, influenced by many genes, each with a small influence (eg, Komiyama et al, 1984). To examine genetic control of sexual maturity in more detail, it was necessary to measure the trait for both sexes in the 16 populations.

Results for age at first egg in pullets were essentially the same in generation 2 as in generation 1 , including degree of overdominance and similar frequency distributions in the parental and reciprocal $F_{1}$ populations. The consistency of these results lent credence to the theories espoused.

In comparison of male and female progeny (generation 2) for age at sexual maturity, it was evident that the female progeny resembled their sires in age at maturity to a greater extent than male progeny resembled their dams. This would be expected in cases of sex-linkage, as daughters would receive a sex-linked gene from their sires, but no corresponding gene from their dams, while sons would receive one allele from each parent. This phenomenon held for the reciprocal $\mathrm{F}_{1}$ 's, the $F_{2}$ 's and the backcross populations in this experiment.

From a genetic perspective, body weight at first egg and weight of the first egg behaved in a fashion similar to age at first egg in pullets. These traits are closely associated and the similar genetic influence is not surprising. 


\section{Changes in fitness}

Both Bantam and low-weight parental populations exhibited some degree of reduced fitness as correlated responses to artificial selection. The low-weight pullets experienced delayed sexual maturity and both types of parental pullets had reduced $\%$ HDNEP. Crossing the 2 parental populations resulted in considerable overdominance in both of these traits, restoring the lost reproductive fitness.

In contrast, neither parental population experienced reduced fitness in terms of $\% \mathrm{NE}$ or in duration of fertility. As a result, there was no improvement in the $F_{1}$ crosses or in any subsequent crosses for these traits. Thus, reduction in fitness due to artificial selection does not necessarily influence all measures of fitness to the same degree.

\section{CONCLUSION}

The results of this study strongly suggest that age at sexual maturity in chickens has a genetic component that is sex-linked and that the trait may be influenced by large effects of one or a few genes and by other genes with minor effects.

\section{REFERENCES}

Dunnington EA (1990) Selection and homeostasis. In: Proc 4th World Congr Genet Appl Livestock Prod, Edinburgh, Scotland, July 23-27, 16, 5-12

Dunnington EA, Siegel PB (1985) Long-term selection for 8-week body weight in chickens - direct and correlated responses. Theor Appl Genet 71, 305-313

Dunnington EA, Siegel PB (1991) Genetic analyses of Bantam and selected lowweight White Plymouth Rock chickens and their crosses. I. Growth, immunoresponsiveness and carcass characteristics. Genet Sel Evol 141-148

Dunnington EA, Siegel PB, Cherry JA (1984) Delayed sexual maturity as a correlated response to selection for reduced 56-day body weight in White Plymouth Rock pullets. Arch Geflugelkd 48, 111-113

Dunnington EA, Zelenka DJ, Siegel PB (1987) Sexual maturity in selected lines of chickens. Proc Br Poult Breeders' Round Table, Edinburgh, Scotland, Sept 16-18 Hays FA (1924) Inbreeding the Rhode Island Red fowl with special reference to winter egg production (preliminary report). Am Nat 58, 43-59

Komiyama T, Nirasawa K, Maito M, Yamada Y, Onishi N (1984) Selection for age at first egg, lighting treatments and crossing effects on sexual maturity in the fowl. XVII World Poult Cong, Helsinki, Finland, 99-100

Kosin IL (1945) The accuracy of the macroscopic method of identifying fertile unincubated germ discs. Poult Sci 24, 281-283

Lerner IM (1954) Genetic Homeostasis. John Wiley and Sons, NY

Siegel PB, Dunnington EA (1985) Reproductive complications associated with selection for broiler growth. In: Poultry Genetics and Breeding (Hill WG, Manson JH, Hewitt D, eds) Longman Group, Harlow, 59-72

Siegel PB, Dunnington EA (1987) Selection for growth in chickens. In: CRC Critical Reviews in Poultry Biology. CRC Press Inc, 1-24 
Stewart J (1969) Biometrical genetics with one or two loci. I. The choice of a specific genetic model. Heredity 24, 211-224

Warren DC (1928) Sex-linked characters of poultry. Genetics 13, 421-433

Warren DC (1934) Inheritance of age at sexual maturity in the domestic fowl. Genetics 19, 600-617

Zelenka DJ, Dunnington EA, Siegel PB (1986a) Growth to sexual maturity of dwarf and nondwarf White Rock chickens divergently selected for juvenile body weight. Theor Appl Genet 73, 61-65

Zelenka DJ, Siegel PB, Dunnington EA, Cherry JA (1986b) Inheritance of traits associated with sexual maturity when populations of chickens reach $50 \%$ lay. Poult Sci $65,233-240$

Zelenka DJ, Jones DE, Dunnington EA, Siegel PB (1987) Selection for body weight at eight weeks of age 18. Comparisons between mature and immature pullets at the same live weight and age. Poult Sci 66, 41-46

Zelenka DJ, Dunnington EA, Cherry JA, Siegel PB (1988) Anorexia and sexual maturity in female White Rock chickens. I. Increasing feed intake. Behav Genet 18, 383-387 